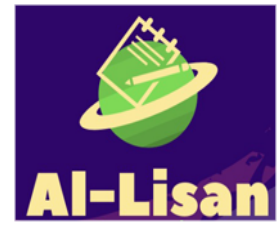

\title{
Investigating The Approaches of English Teachers in Fostering EFL Students' Language Proficiency
}

\author{
Anita Anggraeni ${ }^{1}$ \& Cynantia Rachmijati ${ }^{2}$ \\ anitaenglish26@gmail.com, cynantiarachmijati@ikipsiliwangi.ac.id \\ Institut Keguruan dan Ilmu Pendidikan Siliwangi, Indonesia
}

\begin{abstract}
This research is qualitatively descriptive, intending to define the efforts of English teachers at Boarding school and hereinafter referred to as Pesantren (al-Fatah) to develop students' English language proficiency. Subjects of this study are two English teachers and Students at Pesantren al-Falah. This study also investigates the way of English teaching methods or strategies in the classroom. There are two main instruments to collect data, those are Observation and interview guidelines. The result of the study indicates that the most teaching methods used are still a teacher-centered, direct method and habituation. This is due to the influence of the traditional Arabic learning model which is still largely focused on what is conveyed by the teacher in the classroom. But this Pesantren also implemented a communicative approach to develop the speaking skill of the students. One of the challenges faced is students' negative perceptions of English which assume that English is a western culture that is synonymous with negative things. Therefore, to further strengthen the development of English language skills, English teachers need to be more exposed to English by offering their students even more usual practice and the right media and literature to minimize negative perceptions of Western culture.
\end{abstract}

Keywords: Pesantren; Teaching Methods; English Language Proficiency.

\section{A. INTRODUCTION}

Pesantren is an Islamic educational institution that has a long history and still survives in Indonesia (Mubarock, 2015). Pesantren are also part of a unique education system. Persevere in the traditional form, thick with the nuances of religion and participate actively in the spread of Islam and are led by Kiai or Ustad and produce graduates of the students or then referred to as Santri. Based on the data collection of Pesantren in 2019 from the Ministry of Religion (taken from https://ditpdpontren.kemenag.go.id/web/), there are 28194 Pesantren scattered 
throughout Indonesia. The total number of Santri even reaches more than 3 million people.

In the beginning, Pesantren was managed simply and traditionally. There are no class classification, no curriculum, nor are there any fixed rules in it. As a medium of religious learning, there has never been a contract or request from Santri to the Ustad or teacher to provide a book or learning module, the teachers let alone regulate in detail the materials to be taught. Everything depends on the teachers as the axis of the Pesantren learning system. Starting from the schedule, methods, even what to be taught, all are the authority of a Ustad in full (Haedani, 2004). Two well-known learning models at the beginning of the Pesantren were the non-classical Wetonan learning system and the Sorogan system.

The Wetonan/Bandongan system is a study conducted by a Kiai or Ustad, followed by Santri with no age limit or a measure of intelligence. This model of learning system, reportedly is a method taken from the learning patterns of Arabic scholars. In this system, Kiai or Ustad reads the book, while the Santri each hold their own book by listening to the Kiai or Ustad statement to condemn or interpret the bare book. Another with the recitation of wetonan, sorogan recitation is done one by one, where a Santri read the book one by one in front of Kiai or Ustad then they correct students' mistakes. In this Sorogan learning, a Santri makes it possible to have a dialogue with the Kiai or Ustad regarding the problems being taught. Unfortunately, a lot of time consuming and inefficient to taught to senior students only. Basically, in traditional Pesantren, the level of knowledge taught depends more on the scholarship, the acceptance of students and the type of book used. The weakness of this system is that there are no clear gaps and stages that must be followed by students. There is also no separation between beginner, intermediate and advance level. Even Kiai or Ustad only repeats one book to be taught to his students. (Haedani, 2004).

According to Amien Rais (1987), there are some weaknesses of Pesantren that need to be addressed immediately, including: the alumni who generally have a narrow mind and are not confident when in contact with real life society that develops in line with the progress of science and technology. Another weakness is that Pesantren in general do not equip their students with the various skills needed to face the challenges of life in modern times. And another weakness is that Pesantren are generally closed to 
accept changes therefore it is difficult to keep up with the times.

Pesantren are considered as the roots of Islamic education in Indonesia, also considered as one of the original education systems in Indonesia that is still developing today. During this time, in the community there is an ambiguous view of the Pesantren. On one side of Pesantren is identical with "traditionalism" in a negative sense (left and old-fashioned), but some other circles view Pesantren as a separate entity with characteristics that are not owned by other institutions, including the education system that is currently running. Learning methods that are rooted in based of Islamic learning are also considered unique, one of which is the Bandongan method, the lecture method. In this method the students will take part in learning where they will sit around Kiai or Ustad and explain the material presented. (Afriza, 2013).

With the various demands and changes of the times, of course one way is to renew or modernize Islamic education. Finally, many Pesantren have improved, added a lot of expertise and taught foreign languages, including English in order to follow the development of globalization and the development of education (Andika, 2017).

Some are still trying to follow the traditional roots, but there are also those who have tried to develop, for example, to provide learning in a foreign language, namely English. A number of Pesantren also began to incorporate skills lessons as one of the materials taught. There are skills in farming, farming, sewing, trading and so on (Haedani, 2004)

Even though almost everyone knows the importance of mastering a foreign language, the awareness to learn it does not always run linearly, especially those identified as traditional Pesantren. There are several reasons why foreign languages other than Arabic have received less attention among the Pesantren community. First, there is a psychological obstacle in the form of fear to learn it. During this time when people talk about English for example, what appears in the assumption later is that English is very difficult to learn. Second, there are cultural constraints in the sense that learning English in a Pesantren is considered not a norm. Third, lack of access. Fourth, lack of adequate human resources to develop English. Fourth, a very basic factor is ideological biases where language is understood as part of a particular religion. For example, Arabic is considered as the language of Islam, English as the language of Christians, Chinese as a representation of the language of Confucianism and so on. 
Therefore, it can be seen that Pesantren which trying to be more modern and develop their English language skills are sometimes hit by perceptions, opinions and fears in using the language. As stated by Baekani et al (2017) that most pesantren residents feel they don't need to use English and don't even know English at all. Ihsan on his finding (2011) also stated that in the use of everyday language, students are generally faced with various patterns of choice in language activities namely Indonesian, Arabic, and regional languages. But generally the students or santri are more inclined in using local languages.

Initially, Pesantren Al-Fatah which is located in Gunung Halu, West Bandung, only taught Islamic religious sciences and studying specifically the bare book that became a reference for Islamic scientific traditions in the Pesantren. But along with the development era and there are also demands from the community to hold formal education whose alumni are recognized by the government with the same diploma as the general diploma, Pesantren Al-Fatah finally organizes more formal educational institutions as a Madrasah while still maintaining the characteristics of traditional Pesantren but also balanced with the introduction and development of science and technology, and one of the efforts to develop them is by fostering English language prificiency.

Anto. et al (2018) in their research stated that in a Pesantren environment, especially the modern ones, students are required to be accustomed to using several languages that have become standard in using language as a means of communication. The obligation to use multi-language is intended to improve the competence and language skills of students. With adequate foreign language skills, students are expected to be able to compete in competitions when they have graduated and are ready to enter the community.

Therefore, it is important to address on how the Pesantren Al Fatah would do to fostering their students' English Skill. Departing from the problem, therefore the problems that can be formulated in this study are: How is the learning model and strategies to fostering English skill in Pesantren Al Fatah Bandung? What are the driving forces and obstacles in the process of fostering English in Pesantren Al Fatah Bandung?. 


\section{B. RESEARCH METHOD}

This research approach is a qualitative descriptive, because the data will be presented in descriptive analysis. Whereas qualitative research itself according to Bogdan and Taylor as cited by Lexy.J. Moleong (2006), is a research procedure that produces descriptive data in the form of written or oral words from the people and actors observed. The research location is in Gununghalu Village, Gununghalu District, West Bandung Regency, West Java Province, Indonesia. Primary data sources are data that is directly accessed by researchers (Sugiyono, 2006). In this study the data taken data from observations to English classes and the observational data are the teacher and students. Secondary data sources in this study were drawn from literature studies and related books.

The tools to collect data in this study are interviews, observation and documents. Data obtained from interviews will be combined with data from observation data and documents. Those intruments are used to invetigate in detail how the learning process conducted in the classroom.

Data analysis methods use inductive methods, namely data reduction, data presentation and data verification. In analyzing the data will be used with a literature review on English language learning. The interpretation of the findings will be interpreted based on the literature review and conclusions based on the results of the interpretation that has been prepared.

\section{FINDINGS AND DISCUSSION}

In Pesantren Al Fatah, there are two English teachers. Based on observations in class, there are a number of English learning strategies, those were giving and introducing vocabulary. The teacher reads the vocabulary then followed by the student in a loud voice. The next activity is making conversation activity where students are asked to talk with the other person. The third activity is reading and writing activities and usually the teacher gives worksheets. The students in the class around 40 to 42 students. The teacher focused on the vocabulary lists and then discussing the meaning and the synonym of the vocabulary. After explaining material, English teachers then proceed gave the students the worksheet which is usually a text to be read and translated. After the students finished discussing and translating the text and then the 
students presented in the class of their finished work. Here on this part the student was practicing speaking also listening skill where their peers were presenting their work. The lesson end with teacher summarized the lesson and revising the grammar and vocabulary that were given that day. The teaching method and strategies were similar to the wetonan/bandongan system where Kiai or Ustad reads the book while the students each hold their own book by listening to the teacher's statement to condemn or interpret the bare book.

Based on interviews with English teachers, they stated that the lack of students in English was, among others: students still have a low vocabulary, lack of speaking skills due to low self-confidence and lack of mastering grammar. The teachers try to improve coaching by providing remedial and additional training and even direct communication with students so that students' English skills become better.

Learning strategy according to Kemp (Kemp, 1977) is a learning activity that must be carried out by teachers and students in order that learning objectives can be achieved effectively and efficiently. The efforts to implement lesson plans that have been prepared in real activities therefore the objectives that have been prepared can be achieved optimally, need a method to realize the strategies.

Strategies used can vary, for example through question and answer or lectures. The approach can be interpreted as a starting point or point of view of a learning process. Roy Killen (Killen, 1998) notes that there are two approaches to learning, namely teacher centered approaches and students centered approaches. For teacher centered approaches teachers usually reduce direct learning while student centered is called discovery learning.

Based on the above explanation, it can be concluded that the learning model and strategies to fostering English skill in Pesantren Al Fatah Bandung are:

1. Communicative method

Learning English using a communicative approach can motivate learners, if the steps taken can be used as a forum for learners to practice the language learned for example, dialogue / interact in small groups by utilizing the material available in textbooks and from sources. other. To achieve the goal of communicative English learning there needs to be a methodical didactic change that leads to social interaction and invites learners to get involved in the teaching 
and learning process. Teaching and learning process as above is more directed to CBSA (Active Student Learning Methods). On this method usually teachers let the students to discuss after giving an issue and then they will be having conversation and discussion among their peers where they reached a conclusion and agreement after the students practice their speaking skills. On this communicative method were used in the way of the teacher given the materials and reading aloud the vocabularies then the students were instructed to discussed and translated an English text in a group or working their worksheets.

2. Direct method

Direct method is a method of teaching foreign languages by directly using the foreign language as the language of instruction, and without using the first language of students in teaching. If there are words that are difficult for them to understand, then the teacher can interpret using props, demonstrating, describing and others.

Using this method, the teacher used English directly to the students on each lesson and therefore make students get used to the English exposure. This is the most method that the teacher used since most of the lesson used are teacher centered. This is also where the teacher emphasized on the vocabularies, the definition and the synonym of the word.

For example, where the teacher explained the word "complicated", the teacher urged the students to found out the meaning of the word and then the synonym of the word. Therefore, the students used "difficult", "hard to digest" and other synonyms to describe the words.

3. Habituation Technique

Another thing that is done in the English learning method at Pesantren Al Fatah is through training and habituation activities. The teacher provides training activities especially speaking at the time before class starts or there are certain days where English Day is held so that students are accustomed to using English. It can be concluded that the English learning model and strategies which are used in Pesantren Al Fatah Bandung to fostering their students' English skill are teacher centered, communicative method,direct method and 
also habituation where the teacher is given the materials and students followed along. Maghfiroh's (2016) research results stated that the language discipline in the Pesantren slowly but surely can shape the character of the Santri language, namely by accustoming the use of language in their daily life eventually the Santri will get used to the target language. It is similar result with this study which stated that practice and habituation can be one of the fostering of language skills method that are applied in the Pesantren environment. The observation and interview results revealed some driving forces and obstacles in the process of fostering students' English proficiency in Pesantren Al Fatah.

The obstacles were quite clear, most of the students and teachers put Arabic language as the most special therefore they do not think that English was special or tend to think as "second class language". Other obstacles were the perceptions of the students towards English. The students believed that Arabic language was enough and therefore studying English language is seen as something strange. And most students also identified English with Westerners and therefore have negative assumptions about it. The strong ideology of Islam and the suspicion of the West and the negative effects on English also influence the development and teaching of English. The last perception especially from the students that believed English is difficult and the students weren't as excited in studying English compared to Arabic.

Based on the results of interviews with English teachers and observations, the driving force is the existence of adequate facilities and infrastructure to advance the students to improve their English language skills, especially in speaking skills. This can be seen by the implementation of English Day on certain days where students are required to speak in English.

Therefore, it can be concluded that the driving force is the adequate facilities and qualified infrastructure, and the obstacles is students' negative perceptions on English language who they believed were Westernized and difficult to learn.

The results of this study are in line with what was stated by Solichin (Solichin, 2013) that pesantren should integrate English with Islamic studies to follow the development of civilization and culture thus grow into modern people. 


\section{CONCLUSION}

Pesantren at first who was focus on only religion now has transformed into a better educational institute that also follow the development of globalization. Pesantren Al Fatah is one of those who keeps trying to improve their educational system especially in English. In fostering English skill, it can be concluded that the English learning model and strategies which are used in class are teacher centered, communicative method, direct method and practice of habitual in applying English Day. The driving forces in the fostering English skill is the adequate facilities and qualified infrastructure The obstacles in fostering English skill is the student's negative perception on English language. Therefore, in order to further improve fostering students' English language skills, a higher exposure is needed related to English. In addition to habituation, introducing appropriate media and literature and other activities such as speeches and debates to reduce negative perceptions related to English. In the end, the success of teaching and developing foreign languages, especially English in Pesantren, is determined by many factors, ranging from changing perceptions, methods, availability of facilities and infrastructure. But the most decisive factor is actually the willingness of the Pesantren themselves to be open to accept and realize the importance of English for development.

\section{REFERENCES}

Afriza, H. (2013, October 17). Pesantren sistem pendidikan asli di Indonesia. Retrieved from Khazanah Republika: https://www.republika.co.id/berita/duniaislam/khazanah/13/10/17/mut6fy-pesantren-sistem-pendidikan-asli-indonesia

Andika, M. A. (2017). Pembelajaran bahasa Arab-Inggris di Lembaga Kursus Bahasa Asing (LKBA) pondok pesantren Miftahul Huda. Prosiding Konferensi Nasional Bahasa Arab III (pp. 189-196). Malang: Universitas Negeri Malang.

Anto, P., \& Rahma, F. (2018). Jasus Bahasa : suatu metode pembelajaran bahasa asing di pesantren modern (representasi dalam novel berlatar pondok modern Gontor). Prosiding Pekan Seminar Nasional (Pesona) (pp. 21-33). Jakarta: UHAMKA.

Baekani, A. K., Srisudarso, M., \& Pahlevi, M. R. (Vol 5 No 2 November 2017). Pandangan para ustad dan santri terhadap pelajaran bahasa Inggris di pondok pesantren Salafiyah Darul Ulum Karawang. JUDIKA : Jurnal Pendidikan Unsika, 117-123. 
Chaplin, J. (1958). Dictionary of psychology. New York: Dell Publishing.

Dhofier, Z. (1983). Tradisi pesantren : Studi tentang padangan hidup kyai. Jakarta: LP3ES.

Haedani, H. (2004). Panorama pesantren dalam cakrawala modern. Jakarta: Diva Pustaka.

Ihsan, M. (Vol 2 No 1 Tahun 2011). Perilaku berbahasa di pondok pesantren Adlaniyah kabupaten Pasaman Barat. Jurnal Wacana Etnik, 25-38.

Joni, R. (1984). Pokok pokok pikiran mengenai pendidikan guru. Jakarta: Ditjen Dikti.

Kemp, J. E. (1977). Instructional Design : Plan for unit and course development. New York: Holt, Rinehart and Winston.

Killen, R. (1998). Effcetive teaching strategies. New Castle: Social science press.

Lexy.J.Moleong. (2006). Metode penelitian kualitatif. Bandung: Remaja Rosdakarya.

Maghfiroh, A. (Vol 3 No 2 Tahun 2016). From daily to fluency : melejitkan kemampuan bahasa asing dengan aktivitas bahasa harian. Jurnal Dimensi pendidikan dan pembelajaran, 49-56.

Mubarock, N. (2015, Juni 17). Peran keberadaan pondok pesantren dalam sistem pendidikan di Indonesia. Retrieved from Kompasiana: https://www.kompasiana.com/nafiseka/555c91d3739773871a308730/perankeberadaan-pondok-pesantren-dalam-sistem-pendidikan-di-indonesia

Rais, A. (1987). Cakrawala Islam antara cita dan fakta. Bandung: Mizan.

Solichin, M. M. (Vol 10 No 1 tahun 2013). Inovasi pembelajaran di pesantren : pengembangan pembelajaran bahasa Inggris. Jurnal Nuansa , 223-226.

Sugiyono. (2006). Teknik Penelitian. Yogyakarta: Pines.

Zuhairini. (1992). Sejarah pendidikan Islam. Jakarta: Bumi aksara. 